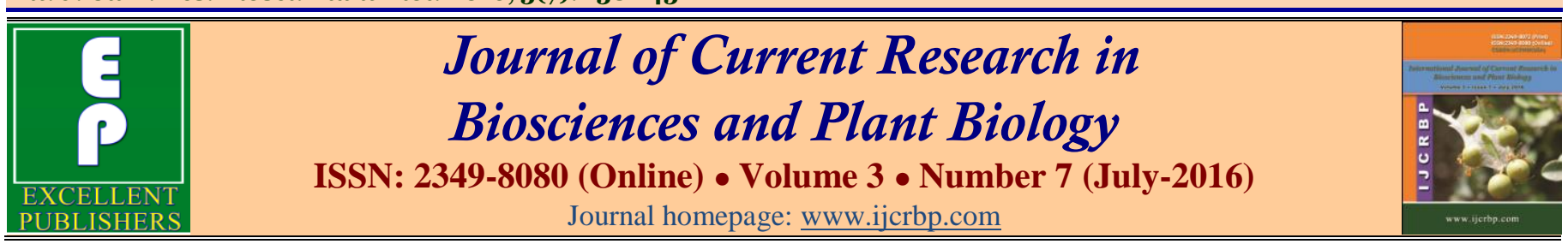

\title{
Impact of the Management of Sandy Soil Fertilization Practices on the Yield of the Intercropping Pearl Millet-Cowpea and on Farmer Income in the Est Sahelian Zone of Mali
}

\author{
Diakalia Sogodogo ${ }^{*}$, Bakary Y. Coulibaly², Béjamé Coulibaly³, Sara Togo ${ }^{4}$, Marie L. \\ Samaké4, Oumar Coumaré 5 and Jacques Togo5
}

${ }^{1}$ Agronome système, Chef ESPGRN/SRA Cinzana, Mali

${ }^{2}$ DEA agronomie, ESPGRN/SRA Cinzana, Mali

3 Agronome Gestion Intégrée de la Fertilité des Sols, ESPGRN/Cinzana, Mali

${ }_{4}^{4}$ M.Sc. Gestion Intégrée de la Fertilité des Sols, ESPGRN/Cinzana, Mali

5 Agronomes vulgarisateurs, AOPP Bamako et Mopti, Mali

*Corresponding author.

\begin{abstract}
A b stract
In the plain of SENO located in the Sahelian Est zone of Mali, farmers grow mainly pearl millet intercropped with cowpea on Sandy-loam soils. In order to improve yields of these crops, farmer apex organization, the association of professional farmer organizations of Mopti has conducted demonstrations on the package of technologies in pioneer farmers' fields. One study was undertaken in this area to assess the impact of this technology package on crop yields and farmer income. The investigations concerned $25 \%$ of 200 producers in the area where 7 farmers were from the control village, 18 and 15 from the first and the second scaling out villages, 10 from the village test. Crop yields and net benefit have proportionally varied according to the increase of technical package contents. The fertilizer option in Bérély was one dominated treatment. The marginal rate of return was $106 \%$ and $87 \%$ in the scaling out village of Anakana and the village test of Téna respectively. Referring to the minimum marginal rate of return of $50 \%$, all the tested packages are economically attractive. However huge efforts should be put in extension activities and agricultural input supply in order to reduce the costs that varied recorded in the test villages.
\end{abstract}

\section{Introduction}

Western Africa is covered by the climatic zones Guinean in south, Sudanese and Sahelian in the center, the Safari jacket in the north. The rainfall decreased from south to north in 1200 to $300 \mathrm{~mm}$ in the last ten years, an average of $200 \mathrm{~mm}$ (Goudet, 1985). The drought of the seventies and eighty pulled a food insecurity in western Africa. It obliged the researchers and the political decision-makers to direct their efforts on the resolution of this problem. In the Sahelian zone, the researches showed that the low organic matter, phosphorus and nitrogen contents are factors limiting production (Penning de Vries and Djitèye, 1982). Stoorvogel and Smaling (1990) and Van der Pol (1992) showed that there are losses of nutritive substances due to the wind and hydric erosions in the systems of production associated with agriculturelivestock farming. The climatic disturbance, the human and animal population growth, and cultural practices brought an overexploitation and a degradation of natural resources (Ministry of the Rural Development, 2002). There is an extensive ceaseless cultivation in the 
marginal lands and the reduction and often the abolition of the lands due to the decline of the siol fertility. The intensification of the work on the soil in many villages caused the transport of the nutrients by runoff water and winds outside fields. The areas of pasture, the agroforests were considerably reduced. Thus it is all the landscape Soudano - Sahelian of western Africa which is facing a deep transformation succeeding on an aridification of the regional microclimate (Roose, 1989).

The soil type in SENO (the present study region) is characterized by its very permeable and poor nutrient contents. The yield on the pearl millet is low in spite of the fact that it is the base food in Mali and significant number of farmers cultivate it [390 612 farms practising the cultivation of pearl millet, 127250 come from the region of Mopti, mainly the SENO (CPS, 2001)]. The beginning of the rainy season is accompanied by wrapping raise of sands and killing all the seedlings which grew on flat surfaces. According to Diallo et al. (2007), the main cultural practices met by the farmers (plowing, sarclo-harrowing, earthing-up) favor the degradation and soil erosion (low level of organic matter, acidification, structural instability).

Traditionally, the farmers always sow on organic mounds made one year in advance during the hoeing of the overwinter cultivation. The results of the previous research works showed that in the lowlands of the SENO, to make a success of the overwinter cultivation, it is necessary to sow on raised beds or on mounds. The sowing on organic mounds (organic raised beds) allowed the sandy soil to accumulate a rate of organic matter that plants can take advantage during their vegetative cycle (Cell Cultural Techniques, 1982). Under the demographic and land pressures on a reduced space, the people developed traditional strategies by basing itself on the rational management of the productive lands, surface water (rain and streaming), animals and biomass (Sabir et al., 2000).

The farmers practise the continuous cultivation of the intercropping of pearl millet-cowpea with a low density of cowpea. The disappearance of the fallow associated with this cultural practice show the bankruptcy of the itinerant agriculture in the SENO. With this report, the use of mineral fertilizers associated with the improvement of the organic matter becomes necessary. Many technical solutions were found within the framework of the restoration soil fertility. However, the variability of the results in the Sahelian space motivated other researches which succeeded on strategies of political management and technical management on field scale (Bationo et al., 1998). The control of the soil erosion with the mulching, the billonnage (organic mounds), the integration of the agriculture and farming practices (Powell and Unger, 1998). The organic amendments in soil were proposed within the framework of conserving soil fertility in Sahel.

Our working hypothesis in this research was that in the same agro-ecological zone, the change of practices of fertilization and/or the combination of soil fertility practices, would improve the crop yield and the income of the farmers. The main objective of the present study was the evaluation of the impact of agricultural practices on soil fertilization at the farmers field in SENO by the Association of the Peasant Professional Organizations on the yield on the intercropping and the income of the farmers. The lands of the SENO extends on circles of Koro and Bankass in the region of Mopti.

\section{Materials and methods}

The project 2013 SHP $005<<$ Supporting Soil Health Consortia in West Africa-facilitating wider uptake of better adapted visible ISFM practices which insists on the positive aspects of impacts on countryman livelihoods >> piloted by the Institute of Rural Economy and financed by AGRA (Wedding Ring for Tea Green Revolution in Africa) through the IITA (International Institute for the Tropical Agriculture) developed a partnership with the Association of the Professional Peasant Organizations (AOPP). It is this executive key peasant association of the project that identified the peasant and peasant sites, the organizations, collaborators, the human resources for the training, the technical, social and logistic aspects of the work.

\section{Zone of the study}

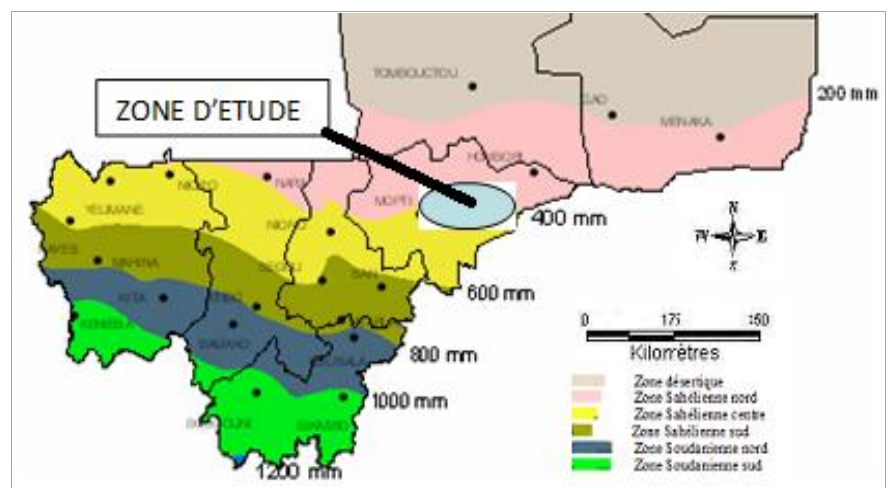

Fig. 1 : Experimental sites in Mali (Source : LABOSEP de Sotuba-Mali, 2000). 
The study was led in a sandy zone convenient for the cultivation of the pearl millet and cowpea (Fig. 1). It has an average pluviometry of $500 \mathrm{~mm}$ characterized these last years by droughts or at the beginning or at the end of season of the cultivation. May, June and July months are dominated by violent rising sands and August is the rainiest month.

In the same agro-ecological zone, three of the villages practising the practices of fertilization of soil spread by the AOPP were compared:

The zone witness dominated by the village of Kiri where the farmers produce traditionally the intercropping of pearl millet-cowpea on formerly raised mounds without the contribution of manure minérale. Mounds were made during the hoeing of the cultivation field of the current wintering. The sowing of the next campaign will be made on these mounts. The densities of sowing were 30000 plants / ha $(1 \mathrm{~m} \times 1 \mathrm{~m}, 3$ plants / poquet $)$ and 3 333 plants / ha $(3 \mathrm{~m} \times 2 \mathrm{~m}, 2$ plants / poquet $)$.

The test village of Téna which sheltered the demonstrations (Microdosage of the fertilizer on the improved varieties in a field with natural regeneration assisted of trees). These demonstrations were led at experimental farmers in charge of the distribution of the information on the use of fertilizers and the improved varieties of pearl millet and of cowpea in the village fields of natural regeneration assisted of trees (Locust tree Albida, Locust tree Senegal and Balanites egyptiaca in the density from 50 to 100 trees / ha). The pearl millet was sown@ 31250 plants / ha $(0.8 \mathrm{~m} \times 0.8 \mathrm{~m}, 2$ plants / poquet) and the cowpea in 7812 plants / ha $(1.6 \mathrm{~m} \times 1.6$ $\mathrm{m}, 2$ plants / poquet).

The zone of distribution groups, the villages of Anakana practising the microdosage of the fertilizer on the local varieties (pearl millet: $1 \mathrm{~m} \times 1 \mathrm{~m}, 3$ plants / poquet; Cowpea: $3 \mathrm{~m} \times 2 \mathrm{~m}, 2$ plants / poquet) and the village of Bérély applying the microcomputing measures on the improved varieties of pearl millet (Toroniou C1) and of cowpea (Korobalen) with the space of sowing of $0.8 \mathrm{~m} \times$ $0.8 \mathrm{~m}$ with 2 plants / poquet for the pearl millet and 1.6 $\mathrm{m} \times 1.6 \mathrm{~m}$ and 2 plants / poquet for the cowpea.

\section{Sampling from producers and gathering of data}

In the zone of study, a total of 200 producers (40 in the test village of Téna, 130 in the zones of distribution) practising the intercropping of pearl millet-cowpea on former mounds with the recommendations in their fields and 30 producers not bringing manure minerals in their fields was identified by the AOPP Mopti (team of Koro). This team has a good knowledge of all the households in the zone of intervention. A sample of $25 \%$ of these producers was selected at random in each of the zones of study. It returned to 7 farmers in the village witness, 18 in the village of Anakana, 15 to Bérély and 10 to Téna.

The data were collected by declarative investigation with each of the selected farmers. The data concerned with the grain yield of pearl millet and of cowpea, the yield of fades sandbank of cowpea. We have on the basis of these data, established the partial budget (Worman et al., 1990) to obtain information on the effect of a change of practice of soil fertilization on the income of the farmer. We considered, for the zone, a rate of marginal return with minimum acceptability of $50 \%$ by the farmers (CIMMYT, 1988), because the technology is not very new in the zone and it modifies only the way of bringing some fertilizer to the crops and the density of cowpea. With regard to the additional investments, the rate of marginal return (TRM) was calculated by dividing the clear marginal profit by the marginal cost expressed in percentage indicating what the farmer plans to gain. The price of $\mathrm{kg}$ of products in the harvest was: 80,100 FCFA for respectively the grain of pearl millet and of cowpea. The statistical analysis of variables and the design of the study and statistical data were made by means of the software INSTAT and the Excel.

\section{Results and discussion}

\section{Yield (efficiency) on the intercropping of pearl millet and cowpea}

The difference between the yields on grain of pearl millet recorded in villages was highly significant (Table 1). The increase of yield was regular in technical package than the others. It was $24.5 \%, 38.2 \%$ and $52.8 \%$ when the microcomputing measures of fertilizer respectively to the system of traditional intercropping, to the system of improved intercropping (improved variety and recommended density) and to the system of improved receiver in the natural regeneration assisted of trees. The grain yield of cowpea varied in a highly significant way between the technical packages (Table 1). The yield increased by $61.3 \%, 69.6 \%$ and $77 \%$ by applying the microcomputing measure to the traditional system, to the improved system of intercropping pearl millet-cowpea, to the improved system combined in the tree assisted system. 
Table 1. Impact of the practices of soil fertilization on the yield (efficiency) on the intercropping of pearl millet-cowpea in the zone of intervention of the AOPP-Mopti in Mali (2015).

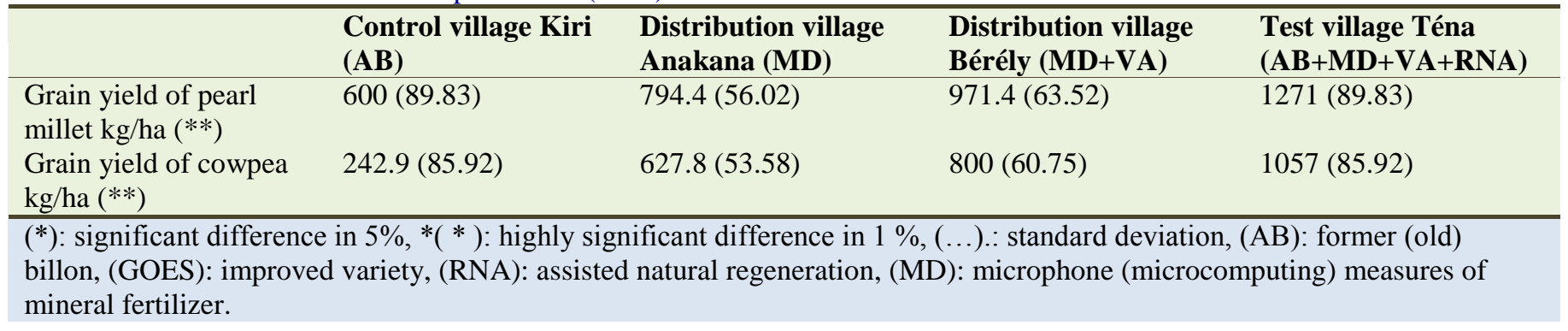

Table 2. Economic profitability of the practices of soil fertilization on the intercropping of pearl millet-cowpea in the zone of intervention of the AOPP-Mopti in Mali (2015).

\begin{tabular}{|c|c|c|c|c|}
\hline Profitability measures & $\begin{array}{l}\text { Control village } \\
\text { Kiri (I) }\end{array}$ & $\begin{array}{l}\text { Distribution } \\
\text { village Anakana } \\
\text { (II) }\end{array}$ & $\begin{array}{l}\text { Distribution village } \\
\text { Bérély (III) }\end{array}$ & $\begin{array}{l}\text { Test village } \\
\text { Téna (IV) }\end{array}$ \\
\hline \multicolumn{5}{|l|}{ Average production $\mathrm{kg} / \mathrm{ha}$} \\
\hline Grain (cowpea) & 280 & 491 & 778 & 1183 \\
\hline \multicolumn{5}{|l|}{ Gross income (FCFA/ha) } \\
\hline Mil (80 FCFA/kg) & 41600 & 63552 & 79120 & 98640 \\
\hline $\begin{array}{l}\text { Total } \\
\text { Variable costs }\end{array}$ & 69600 & 1236332 & 156920 & 216940 \\
\hline $\begin{array}{l}\text { Improved seeds of pearl millet } \\
(500 \mathrm{FCFA} / \mathrm{kg})\end{array}$ & - & - & 2500 & 2500 \\
\hline $\begin{array}{l}\text { Improved seeds of cowpea } \\
(850 \mathrm{FCFA} / \mathrm{kg})\end{array}$ & - & - & 17000 & 17000 \\
\hline $\begin{array}{l}\text { Manpower to sow cowpea, manuring } \\
\text { fertilizer ( } 800 \mathrm{FCFA} / \mathrm{hj})\end{array}$ & 32800 & 48800 & 57600 & 63200 \\
\hline $\begin{array}{l}\text { Manpower for weeding } \\
\text { (6 000 FCFA/j of plough) }\end{array}$ & 24000 & 24000 & 24000 & 36000 \\
\hline Total variable costs (FCFA/ha) & 67800 & 95360 & 126320 & 143920 \\
\hline Marginal net benefit (FCFA/ha) & 1800 & 30972 & 30600 & 73020 \\
\hline
\end{tabular}

\section{Economic analysis}

The earnings of the change of option of fertilization with regard to the control were from 29172 FCFA to Anakana, 28800 FCFA to Bérély and 71220 FCFA to Téna (Table 2). In the village of Anakana, the additional cost compared to the control was 27560 FCFA with a difference of net profit (MN) of 29172 FCFA for a marginal rate of transformation (TRM) for 106\%. The option of Bérély was dominated because of not offering an upper net profit (Table 3). The additional cost to Téna with regard to the control was 48560 FCFA with a difference of margin of 42048 FCFA with a TRM of $87 \%$.

The package of Anakana (traditional system of intercropping + microdose) offered the best TRM. By referring to the minimum rate of $50 \%$, the package of Téna with $87 \%$ of TRM is also interesting.

1) Control village; 2) village bringing the microcomputing measures of fertilizer to the traditional system of intercropping pearl millet-cowpea; 3) village bringing the microcomputing measures of fertilizer to the improved system of intercropping (new density + new varieties of pearl millet and of cowpea); 4) village bringing the microcomputing measures of fertilizer to the improved system of intercropping in a field with natural regeneration assisted of trees.

The investments in the practices of soil fertilization allowed a significant improvement in the grain yields of pearl millet and of cowpea. The improvement of yields on 
the harvests can be made in a spectacular way with the application of mineral fertilizers at the time of the sowing or after the crop growth (WOCAT, 2009). In the other practice, the net profit and the production cost increased. The improvement of the profit becomes a positive element in this intervention (Belemvire et al., 2008). Because there is a blocking in the adoption of technologies when the farmer ignores the profit which he can have of his investment or when he is lacking capital and information about the technology (Odendo et al., 2007).

Table 3. Marginal analysis in the production of the association pearl millet-cowpea in the SENO, during 2015.

\begin{tabular}{llllll}
\hline Trial villages & Total variable costs & Net profit & $\begin{array}{l}\text { Variation in net } \\
\text { profit }\end{array}$ & Variation costs & $\begin{array}{l}\text { Rate of marginal } \\
\text { profitability }(\%)\end{array}$ \\
\hline Kiri & 67800 & 1800 & & & \\
Anakana & 95360 & 30972 & 29172 & 27560 & 106 \\
Berely & 126320 & 30600 & $\mathrm{D}^{*}$ & - & - \\
Tena & 143920 & 73020 & 42048 & 48560 & 87 \\
\hline D* Dominant treatment.
\end{tabular}

In view of the TRM, the change of the traditional practice in that of the contribution of package measures in the traditional practice gets the best of $106 \%$ rate. But when we consider the minimum TRM of $50 \%$, the practice of fertilization (former mounds + microdosage measures + improved variety + RNA) with a TRM of $87 \%$ is also attractive. Already, there is a cowpea in the system which can fix the nitrogen from atmosphere for the synthesis of protein and the fertilization of soil. The RNA consists in protecting and in managing the trees which grow spontaneously in their fields. These trees contribute to the nitrogenous nutrition by the fixation of nitrogen in the soil.

The production cost raised in the last practice demands that capacities are beforehand taken: got in touch with suppliers of inputs and the institutions of microfinance, design of infrastructures for inputs storage and harvest, access to the marketting of farm produces.

\section{Conclusion}

The analysis of the various estimates shows the enormous potentiality of intercropping pearl milletcowpea in the SENO region. The alternative practices of soil fertilization gave higher grain yield than control. The net profit of the farmer increases as the production cost at the same time when we pass of another option. The obtained net earnings are 1800 FCFA in the control village Kiri, 30972 FCFA to Anakana, 30600 FCFA to Bérély and 73020 FCFA to Téna, the test village. The economic analysis by using the minimum TRM of $50 \%$, shows that all the alternatives of soil fertilization to Anakana and Téna are attractive (106\% to Anakana and $87 \%$ to Téna). In spite of the highest net profit to Téna (73 020 FCFA), the farmer engages the highest cost in this site. If in the practice, silver became a limiting factor, it is interesting for the farmer to practise the option of the contribution of microdose measures to the system of traditional intercropping in the village of Anakana.

\section{Conflict of interest statement}

Authors declare that they have no conflict of interest.

\section{Acknowledgement}

In the term of this study, we sincerely thank AGRA and IITA for their financial support, the staff of the AOPP / Mopti and the key informants of the zone for all services provided. Our thanks also go to all the people contacted in villages-control, test and of distribution.

\section{References}

Akbar Bationo, A., Lompo, F., Koala, S., 1998. Research on nutrient flows and balances in West Africa: State-of-theart. Agric. Ecosyst. Environ. 71, 19-36.

Belemvire, A., Maiga, A., Sawadogo, H., Savadogo, M., Ouédraogo, S., 2008. Évaluation des impacts biophysique et socio-économiques des investissements dans les actions de gestion des ressources naturelles au nord du plateau central du Burkina Faso. Rapport de synthèse. 94 pages. Mai 2008. Etude Sahel Burkina Faso.

Cell Cultural Techniques, 1982. Rapport annuel sur les activités de recherche. Commission technique spécialisée sur les cultures vivrières et oléagineuses. IER/SRCVO/Sotuba. 25p.

CIMMYT, 1988. From Agronomic Data to Farmer Recommendations: Economic Training Manual. (International Maize and Wheat Improvement Centre). Completely Revised Edn. CIMMYT, Mexico

CPS, 2001. Recueil des statistiques du secteur rural. Ministère de développement rural/Cellule de Planification et de Statistiques/Mali. 
Diallo, D., Bengaly, A., Ouédraogo, A., Traoré, K., 2007. Efficacité des pratiques de gestion de l'eau et des sols en agriculture céréalière pluviale au Mali : cas du secteur de Banamba. Acts des JSIRAUF, Hanoi, 6-9 Novembre 2007.

Goudet, J.P., 1985. Equilibre du milieu naturel en Afrique tropicale sèche. Végétation ligneuse et désertification. Bois Forêts Trop. 207, 3-15.

Ministry of the Rural Development, 2002. Plan national pour la gestion intégrée de la fertilité des sols Au Mali.

Odendo, M., Ojiem, J., Bationo, A., Mudeheri, M., 2007. OnFarm Evaluation and Scaling-up of Soil Fertility Management Technologies in Western Kenya. Kenya Agricultural Research Institute (KARI), P.O. Box 169, Kakamega, Kenya.

Penning de Vries, F.W.T., Djite`ye, M.A., 1982. La productivité des pâturages Sahéliens. Une étude des sols, des végétations et de l'exploitation de cette ressource naturelle. Agric. Res. Rep. 918, Pudoc, Wageningen, The Netherlands.

Powell, J.M., Unger, P.W., 1998. Alternatives to crop residues for sustaining agricultural productivity and natural resource conservation. J. Sust. Agric. 11(2-3), 59-84.
Roose, E., 1989. Gestion conservatoire des eaux et de la fertilité des sols dans les paysages soudano-sahéliens de l'Afrique Occidentale. Soil, Crop, and Water Management Systems for Rainfed Agriculture in the Sudano-Sahelian Zone: Proceedings of an International Workshop, 7- 11 Jan 1987.

Sabir, M., Roose, E., Merzouk, A., Nuri, A., 2000. Techniques traditionnelles de gestion de l'eau et de lutte anti érosive dans deux terroirs du Rif occidental (Maroc). 17p.

Stoorvogel, J.J., Smaling, E.M.A., 1990. Assessment of Soil Nutrient Depletion in Sub-Saharan Africa: 1983-2000. Vol. 1. Main Report. DLO - Winand Staring Centre, Wageningen, The Netherlands. 137p.

Van der Pol, F., 1992. Soil Mining an Unseen Contributor to Farm Income in Southern Mali. Royal Tropical Institute Bulletin 325, KIT, Amsterdam, The Netherlands.

WOCAT, 2009. Bonnes pratiques de GDT adaptées à 1'Afrique subsaharienne. $2^{\text {nd }}$ Partie. WWW.WOCAT.Net

Worman, F., Norman, O., Ware-Snyder, J. (Eds.), 1990. Agricultural Technology Improvement Project. Farming Systems Research Handbook for Botswana ATIP RP3. Department of Agricultural Research, Ministry of Agriculture, Botswana.

\section{How to cite this article:}

Sogodogo, D., Coulibaly, B. Y., Coulibaly, B., Togo, S., Samaké, M. L., Coumaré, O., Togo, J., 2016. Impact of the management of sandy soil fertilization practices on the yield of the intercropping pearl millet-cowpea and on farmer income in the Est Sahelian zone of Mali. Int. J. Curr. Res. Biosci. Plant Biol. 3(7), 138-143. doi: http://dx.doi.org/10.20546/ijcrbp.2016.307.019 